\title{
Effect of Image Quality Service and Schools Parents of Satisfaction in Surabaya.
}

\author{
Wiwik Retnaningsih \\ Management Science Department, Faculty of Economics, 17 Agustus 1945 University, Surabaya , \\ East Java of Indonesia.
}

\begin{abstract}
This study aimed to determine the effect of Quality of Service (X1), the image of School (X2) either partially or simultaneously to the satisfaction of Parents' (Y) in the School of Surabaya. This study has four hypotheses, namely: (1) there is an allegation of a positive and significant relationship between service quality in partial satisfaction of the Parents' School in Surabaya. (2) there are allegations about a positive and significant relationship between the partial image of the Parents 'Satisfaction (Y) in the School of Surabaya, (3) there is a suspicion of a positive and significant relationship between service quality and image simultaneously on Parents' Satisfaction in School Surabaya, (4) there is suspicion between the two independent variables and the image and quality of service, quality of service is the most significant effect on increasing Satisfaction Parents' School in Surabaya? ..

The subjects of this study were parents of students with a sample of 100 respondents (stratified random sampling). Data was collected using a modified Likert scale. The data obtained and analyzed with the help of Program Statistics for Social Sciences (SPSS) version 16.00 for Windows with multiple regression analysis. The results showed that, the partial effect of Service Quality on job performance 4.336 (the t-table 1.980). Based on hypothesis testing a significant difference between Service Quality with Parent Satisfaction, because $t$-count more than $t$-table,. Effect of the partial image of the school to the 2440 performance (on t-table 1.980).

Based on hypothesis testing a significant difference between the image of the School Parent Satisfaction, for t-count more than t-table., Along the influence of two variables and images Schools and Quality Service to the satisfaction of the parents are at 0.815 or $81.5 \%$. Based on the hypothesis can be concluded, that the image of the school and the quality of service simultaneously significant effect on Parent Satisfaction, Service Quality (XI) and Parents' Satisfaction (Y) with a value of 0.802 linkages and higher than the value of the image of School 0774. So the quality of service that most significantly affect parental satisfaction. Keywords: Quality Service, School Parents, effect of image, Satisfaction.
\end{abstract}

\section{Introduction.}

The need for quality education is now getting the attention of the public. Today most people are willing to sacrifice a higher cost just to get a quality education and will promise a better future. Education today will determine the direction in which a person will continue higher education.

One of the educational institutions in Surabaya is a vocational high school in Surabaya. This school is a formal educational institution. School in Surabaya have programming skills such as accounting, office administration and marketing. SMK in Surabaya has several facilities to support various academic activities, some facilities in vocational high schools are located in Surabaya is: laboratory, computer and language, school health unit (UKS), cafeteria, mini banks and libraries. Data show that from the year 2005 - 2010 there was an increase of students who withdrew, 24 students who dropped out in the 2005-2006 school year, 26 students dropped out of school in the 2006-2007 school year, 25 students dropped out of school year 2007-2008, 22 students dropped out in the 2008-2009 school year and 28 students dropped out in the 2009-2010 academic year. Improvement can occur because of dissatisfaction with service education experienced by students in vocational high schools in Surabaya. Therefore, the school felt the need to implement strategies for the students to complete their education at vocational schools. One of them is to be done is to increase student satisfaction in carrying out studies in vocational high schools. But these efforts to improve customer satisfaction is always closely linked to the quality of services provided by the school.

According to MN Nasution (2005:3) (1), the importance of quality can be explained from two angles, ie angles operational management and marketing management conceptual framework. 
Picture: conceptual framework.

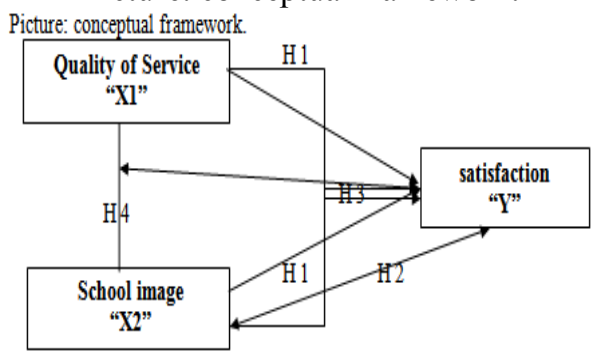

Source: processed some previous research.

\section{Basis Theory.}

Quality of service is a form of the totality of characteristics of goods or services that demonstrate its ability to meet customer needs, whether it's obvious or hidden (Kotler, 2000) (2) Quality of service can be measured by looking at how effective the service to narrow the gap between the expectations of the services provided. Tjiptono (2005:110 (3)) states that quality is a dynamic state associated with products, services, human resources, processes and environments that meet or exceed expectations. For example, location, cost, accreditation status, the number and qualifications of the staff and teachers.

Furthermore Tjiptono, et al $(2008$; 67) (3) states that in order to create customer satisfaction, quality of products offered by the organization to be eligible. Because the quality of a number of levels: the universal (the same everywhere), culture (depending on your cultural values), social (shaped by socio-economic class, ethnic group, family, friends relationship), and personal (depending on each individual's preference or taste). Service quality contributes significantly to the development of differentiation, positioning, and marketing competitive strategy of any organization, whether manufacturing companies and service providers. Figure deemed to affect the minds of consumers through the combined effects of advertising, public relations, physical image, from mouth to mouth, and a real experience with goods and services (Norman in Kandampully \& Dwi Suhartanto, 2000:347) (4). Image is also defined as the overall impression formed from the minds of the public about an organization. It is associated with the name, the form of architecture, products / services, and the impression of the quality of communication by each worker organizations interact with clients (Nguyen \& LeBlanc, 2002:243) (5). Meanwhile Kotler said image is a set of beliefs, ideas and impressions that are owned by for an object (Kotler, 2000:208) (3). Image is built by what the consumers or the public feel and know about the company, the role of advertising companies are very powerful influence in addition to the creation of corporate image information by word of mouth from customers. Personal experience, information received from others, and promotion by all companies can have an impact on the image of corporate customers (Kurtz \& Clow, 1998:4) (6). Manufacturers in school management is very aware that to make a bigger school (have lots of students) then the parent satisfaction factors become very important factor for parents to meet the satisfaction of school education to win the competition. Determine the level of parental satisfaction with the school can do to share strategies to improve school quality. This concept is consistent with the view of "Quality Movement" is a systematic approach to improve production and services based on customer satisfaction that parent satisfaction with the influence of satisfaction on customer loyalty and commitment from the community to the school where their children get an education. So it is not surprising that the current strategy is chosen to be a successful school / success more focused / consumer satisfaction oriented (parents as a determinant of the decision to the student) in order to win the competition in the market "Customer Satisfaction Study" is one of the important activities of the marketing results).

School as an institution of education providers should really focus on improving school education to have the satisfaction of parents so that parents will defend their children learn in school. Dealing with so many schools there and offer special programs / competitive advantage and differentiated for each school to be very important in influencing the choice of parents in educating their children. Only schools that have a school perceived image (image of the school) a good that can affect the level of satisfaction of parents find school. Market development is so rapid now encourages consumers to consider the characteristics of the brand image than products offered. Satisfaction of parents in the education sector can be attributed as customer satisfaction, commitment and loyalty that affect parents of school children. Parents who are not satisfied to move their children to another school. Indeed, in terms of school, parents are the main customers of the education offered by the school, but parental satisfaction is key to customer satisfaction with the school..

According to Kelly, 2009 (7), school quality can be seen from the ten characteristics indicate that 1. The attitude of the staff in the office..

2. Attitude of the principal.. 
3. Composition of the mixture of old and new teachers..

4. Student-centered..

5. Supervision / mentoring program..

6. Political inter-unit minimum..

7. Participation of each staff..

8. Collaboration between staff..

9. Regular communication and open / what it is..

10. Parental involvement.

Means by Supranto (2006) (8), the school environment is safe, bathroom / toilet clean, comfortable classrooms, Surabaya is located in convenience location, protected from noise, a Health Unit comfortable, clean school environment, a complete collection of library facilities, sports field complete, full-class facility. Infrastructure according Supranto (2006): (8). Large parking area, sports field complete, comprehensive computer laboratory equipment, Surabaya provide as a business center for entrepreneurship, Surabaya provide specialized job market ..

Teachers according Supranto (2006) (8), Teacher to deliver lessons well, teachers come on time in the classroom to teach, teachers be fair to all students, teachers are prepared, teachers master the subject matter, never miss the teacher to teach, teachers teach subjects according to educational background, teachers communicate effectively and respectfully with parents, Employees According Supranto (2006) Friendly employees serve students, employees are able to cater to parents of students with good, skilled employees with administrative, employee neat appearance, library staff able to serve students well. Curriculum by Supranto (2006), students practice to gain competence, vocational subjects that have gained useful to increase potency, the subject matter presented in accordance with the needs of the workforce, each subject was given a lesson of entrepreneurship. According to the government Supranto (2006) (8) of the Regulation is applied in a fair school, guidance counselors implement development programs in the form of counseling, school rules apply to all students. Quality and Quality of Service are appropriate to define quality, but the quality can be determined. The concept of quality itself is often regarded as a measure of the relative goodness of a product or service consisting of quality as a function of the quality of the design of the product specifications, whereas quality of conformance is a measure of how many products are able to meet the requirements or quality specification. Suitability for use as a quality (fitness for use). Definition emphasizes the orientation on meeting customer expectations. (Josep M. Juran in FandyTjiptono, 2005:11) (9), Definition Picture considered to influence the minds of consumers through the combined impact of advertising, public relations, physical image, from mouth to mouth, and a real experience with goods and services (in Kandampully \& DwiSuhartanto Norman, 2000:347) (10). Image is also defined as the overall impression formed from the minds of the public about an organization. It is associated with the name, the form of architecture, products / services, and the impression of the quality of communication by each worker organizations interact with clients (Nguyen \& LeBlanc, 2002:243) (11)..

Satisfaction in Education, Parent satisfaction in the field of education can be attributed as customer satisfaction, commitment and loyalty that affect parents of school children. Disgruntled parents can transfer their children to another school. Indeed, in terms of school, parents are the main customers of the education offered by the school, but parental satisfaction is key to customer satisfaction with the school..

According to Kelly, 2009, (12) school quality can be seen from the ten characteristics showed that:

1. The attitude of the staff in the office.

2. Attitude of the principal.

3. Composition teachers mixture of old and new.

4. Centered student.

5. Program supervision / mentoring.

6. Politics between the units is the minimum.

7. Participation of each staff.

8. Collaboration between staff.

9. Regular communication and open / what it is.

10. Parental involvement.

\section{Research Methods..}

In determining the number of samples that the author uses a formula presented by Sugiyono $(2010 ; 81)$ (13) as follows:

$$
\mathrm{n}=\frac{\mathrm{N}}{1+\mathrm{N}(\mathrm{d})^{2}}
$$

Description:

$\mathrm{n}$ : The sample size.

N: Large populations.

D: The level of confidence / precision desired 
Methods and Data Analysis Techniques.

a. Regression Analysis.

Multiple linear regression analysis with the analysis of the following equation:

$\mathrm{Y}=\mathrm{a}+\mathrm{b} 2 \mathrm{X} 2+\mathrm{b} 1 \times 1+\mathrm{b} 3 \times 3+\mathrm{b} 4 \times 4+\mathrm{b} 5 \times 5+\mathrm{b} 6 \times 6+\mathrm{b} 7 \times 7$.

where

Y: X 1 Parent Satisfaction: Reliability.

A: Constant X2: Responsiveness.

b1: Regression coefficients x 1 X3: Security.

b2: Regression coefficient of $x 2 \times 4$ : Empathy.

b3: Regression coefficient of x 3 x5: Physical Evidence.

b4: Regression coefficients X6 x4: Functional.

b5: Regression coefficient of $\times 5 \times 7$ : Emotional.

b6: Regression coefficient of $x 6$.

b7: the regression coefficient of $x 7$.

b. Significance testing.

\section{Coefficient of Determination Test}

Coefficient of Determination (R) 2 is the sum of the extent of compliance with the regression equation data. The coefficient of determination (R) 2 also shows the proportion of the dependent variable explained by the independent variables, the greater the $(R) 2$, the greater the proportion of variable explained by the independent variables, otherwise if (R) 2 is getting smaller, it can be said that the contribution of the variable that the variable is smaller that depends. More details can be said that the magnitude of the coefficient of multiple determination (R) 2 is between $0<\mathrm{R} 2<1$. The coefficient of determination can be calculated by the equation:

\section{F-Test.}

$$
R^{2}=\frac{J k(r e g)}{\sum Y^{2}}
$$

Where :

R2: coefficient of determination.

$\mathrm{Jk}(\mathrm{reg})$ : The number of squares regression.

$\Sigma$ Y2: Total squared correlation.

F-test was used to determine the level of significance of the influence of variables - the independent variable (reliability, responsiveness, assurance, empathy, tangibles) simultaneously on the dependent variable (customer loyalty). Equation F-Test.

$$
\mathrm{F}_{\text {count }}=\frac{R^{2} / k}{\left(1-R^{2} /(n-k-1)\right)}
$$

Where :

R2: coefficient of multiple correlation.

$\mathrm{n}$ : Number of samples.

$\mathrm{k}$ : The number of independent variables Hypothesis testing steps are as follows:

a). formulate hypotheses.

Ho $=$ There is no positive effect of variable reliability, responsiveness, assurance, empathy, and tangibles simultaneously to the satisfaction of the parents. There are positive effects of positive reliability, responsiveness variables..

$\mathrm{Ha}=$ assurance, empathy, and tangibles simultaneously to the satisfaction of the parents. b) By using a confidence level of $\alpha=0.5$.

c). testing criteria.

* If $\mathrm{F}$ count $>\mathrm{F}$ table then (Ho is rejected and Ha accepted) means that there is no positive effect of variable reliability, responsiveness, assurance, empathy, and physical evidence, as well as to the satisfaction of the parents..

* If the $\mathrm{F}$ calculated $<\mathrm{F}$ table then (Ho accepted and Ha rejected) means that there is a positive effect of variable reliability, responsiveness, assurance, empathy, and physical evidence, as well as to the satisfaction of the parents. 


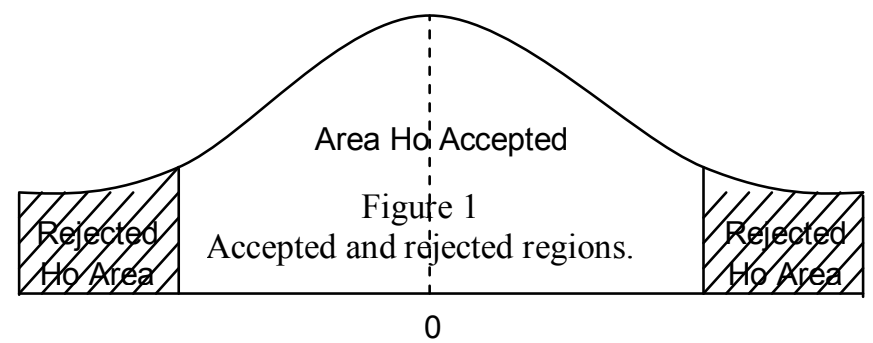

\section{T-test.}

T-tests were used to verify or test the partial regression coefficients so that the known variables Reliability (X1), responsiveness (X2), Assurance (X3), Empathy (X4), and tangible (X5), simultaneously to the satisfaction of Parents (Y).

$\mathrm{T}$ test can be calculated by the equation:

t-count $=$

where :

regression coefficient: $b$

Sc: the value of the standard error

Hypothesis testing steps are as follows

a). formulate hypotheses

* Ho $=$ There is no positive effect of variable reliability, responsiveness, assurance, empathy, and tangibles, partly for the satisfaction of the elderly

$* \mathrm{Ha}=$ There is a positive effect of variable reliability, responsiveness, assurance, empathy, and tangibles, partly for the satisfaction of the elderly

b). Using a confidence level of $\alpha=0.5$

c). testing criteria

* If $t$ count $>t$-table then (Ho is rejected and Ha accepted) means that there is a positive effect of variable reliability, responsiveness, assurance, empathy, and tangibles, partly for the satisfaction of the parents.

* If $\mathrm{t}<\mathrm{t}$-table then (Ho accepted and Ha rejected) means that there is a positive effect of variable reliability, responsiveness, assurance, empathy, and tangibles, partly for the satisfaction of the parents.

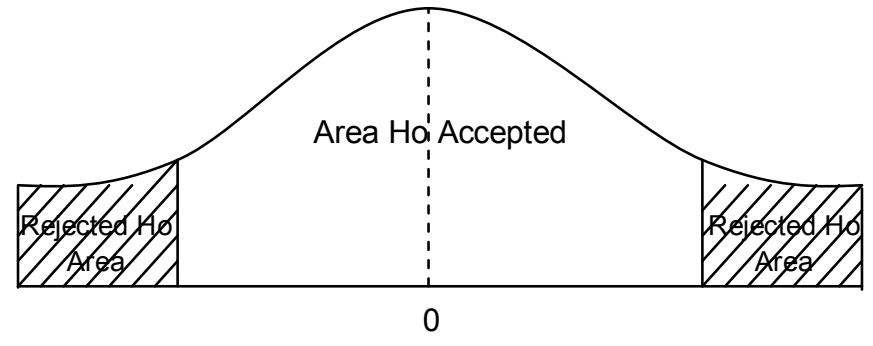

Figure 2

Testing the hypothesis.

Accepted and rejected regions.

To explore the data, it is necessary to analyze the data to find the influence Quality of Service (X1), School Citra (2), Parent Satisfaction (Y)..

Furthermore, hypothesis testing is done by:.

a. T-test.

Testing is done by comparing the t-value calculated by the $\mathrm{t}$-table. If $\mathrm{t}>\mathrm{t}$-table, then Ho is rejected and $\mathrm{H} 1$ is accepted..

1. Effect of Service Quality on Satisfaction Parents.

To determine the effect of Service Quality Of Parent Satisfaction statistical tests are needed. So to test them using statistical hypothesis as follows:

Ho :: Quality Satisfaction services significantly influence parents'.

$\mathrm{H}: \neq 0$ : The quality of service significantly influence parent satisfaction..

With Test Criteria: Reject Ho if T sig count $>t$ table sig.

Table partial effect on the quality of testing services to. 
Parents of students satisfaction

\begin{tabular}{|l|l|l|l|}
\hline Structural & T count & T table & Conclusion \\
\hline pyx 1 & 4,336 & 1,980 & $\begin{array}{l}\text { Ho rejected found } \\
\text { significant effect }\end{array}$ \\
\hline
\end{tabular}

Source: Data processed by SPSS 16.

of the calculation shows that the calculated $t$ value is 2.440 with a significant level of $0.005(5 \%)$ degrees of freedom $=\mathrm{n}-1$ or $100-1=99$ and testing is done with two sides 2 (tail). Obtained t-table is 1.980 . There fore $\mathrm{t}$ count $>\mathrm{t}$ table 2.440>1.90), then Ho is rejected $\mathrm{H} 1$ is accepted. That means a significant impact on satisfaction Schools Parents picture '. In other words it helps in improving the image of the school parent satisfaction. See Appendix $16 .$.

\section{Regression line equation..}

Regression equation used to determine the effect of all independent variables on the dependent variable. A coefficient table:.

A coefficient table Coefficient

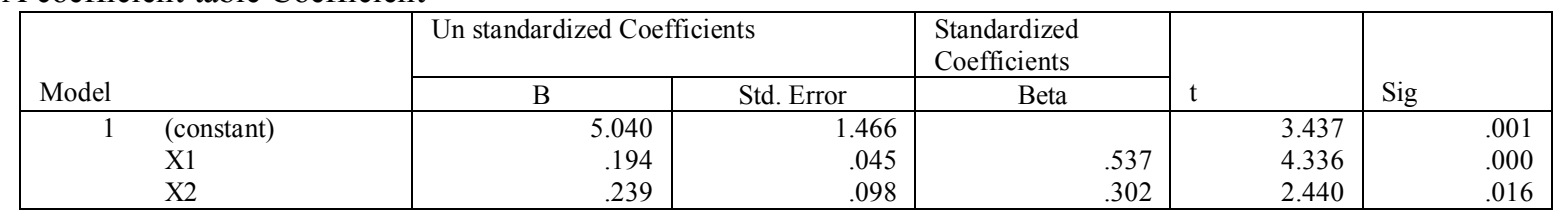

Dependent variable: $Y$

Source: Data processed by SPSS 16

a. Describes the regression equation. In the regression equation coefficients column un standard obtained: $\mathrm{Y}=5.040 \mathrm{X} 10.1940 .239 \mathrm{X} 2$.

where in:

$\mathrm{Y}=$ Parent Satisfaction.

$\mathrm{X} 1=$ Quality of Service.

X2 = Picture School.

b. Constants of 5040 states that if there is variable quality of service and the image of the school parent satisfaction fixed (constant) of 5.040. That is, if the variable quality of service and the image of the school is not listed, parent satisfaction will remain.

c. Regression coefficient of X1 (Service Quality) number 0194. States that whenever there is a 1 in service quality will affect '0194 Parent Satisfaction with 0,045 errors show the influence of other independent variables.. d. Regression coefficient of X2 (School of Image) from 0239, shows that whenever there is a 1 in the school's image would affect Parent satisfaction with an error of 0.239 to 098 show the influence of other independent variables.

\section{F-test}

Testing is done by comparing the count with another FF-table. If $\mathrm{F}$ count $>\mathrm{F}$ table, Hi Ho rejected and accepted ...

Effect of Service Quality and Satisfaction Image School Parents'

To determine the effect of Quality of Service (X1) and the School of Image (X2) of the Parent Satisfaction '(Y), then testing using the F-Test testing is done by comparing the value of the F-table. If the value of the F-count $>\mathrm{F}$ table means that the independent variable $\mathrm{X}(1 \ldots \mathrm{n})$ simultaneously affect the dependent variable (Y). To determine the Quality of Service (X1) and the School of Image (X2) of the Parent Satisfaction '(Y) using the following hypothesis: Ho :: no significant effect between Quality of Service (X1) and School Pictures (Y). Hi: $\neq$ $\neq \neq 0$ : at least $\neq 0$ with the test criteria: Ho is rejected if the $\mathrm{F}$ count $>\mathrm{F}$ table. To test this hypothesis, requires the following:.

Variant Analysis Table

\begin{tabular}{|c|c|c|c|c|c|}
\hline Model & Sum of Squares & $\mathrm{Df}$ & Mean Square & $\mathrm{F}$ & Sig \\
\hline 1 Regression & 817.044 & 2 & 408.522 & 96.089 & $.000^{\mathrm{a}}$ \\
\hline Residual & 412.396 & 97 & 4.252 & & \\
\hline Total & 1229.440 & 99 & & & \\
\hline
\end{tabular}

a. Predictors: (constant), X2, X1

b. Dependent Variable: Y

Source: Data processed with SPSS 16.

Based on the table above, it appears that as many as $96.089 \mathrm{~F}$ with a significance level of F0, 05 (V1 = 2, $\mathrm{V} 2=97) \mathrm{F}$ values obtained for 2.70 . Since $\mathrm{F}$ count $>\mathrm{F}$ table $(96.089>2.70)$ or the value of $\mathrm{n}$ significance (probability) is much smaller than 0.000 .05 (a) then Ho is rejected and Hi is accepted. It can be concluded that the Quality of Service (X1) and the School of Image (X2) simultaneously significant effect on Satisfaction Parents' ... 
Table Square Multiple Correlation

\begin{tabular}{|l|l|}
\hline Variable & Estimate \\
\hline Parents' Satisfaction & 0,815 \\
\hline
\end{tabular}

Sources: Data from the statistical calculation
Coefficient of Determination (Square Multiple Correlation) is a coefficient that is used to determine the contribution of independent variables to changes in the dependent variable changes. Variance in parenting satisfaction variable of $81.5 \%$ can be explained by the variable quality of service and the image of the school. The remaining $18.5 \%$ is explained by other variables not examined..

\section{Discussion and interpretation.}

Impact of service quality and image of the school to the satisfaction of the parents in Surabaya. The results showed that there are significant quality of service along with a 5\% risk of error, while partially significant service quality and image of the school with the results of the study to the satisfaction of both parents simultaneously or partially with an error risk of $5 \%$ is also significantly..

Processing effects of service quality and image of the school to the satisfaction of the parents

\begin{tabular}{|l|l|l|l|l|}
\hline Hypothesis & $\begin{array}{l}\text { Coefficient } \\
\text { Path (p) }\end{array}$ & Determinant (\%) & Significant & Conclusion \\
\hline $\begin{array}{l}\text { Conditions of service quality on Parents' } \\
\text { Satisfaction }\end{array}$ & 0,537 & 53,7 & 0,00 & Ho rejected \\
\hline $\begin{array}{l}\text { Image School of influence on Parents' } \\
\text { Satisfaction }\end{array}$ & 0,302 & 30,2 & 0,016 & Ho ditolak \\
\hline $\begin{array}{l}\text { Service Quality and Image School of } \\
\text { influence on Parents' Satisfaction }\end{array}$ & 0,815 & 81,5 & 0,00 & Ho ditolak \\
\hline
\end{tabular}

Significant level of 0:05

Based on the results of simultaneous data processing, data processing Based on the results simultaneously, Service Quality and image of the school affect parental satisfaction. Thus the partial data processing, such as Quality of Service demands also affect the image of the school and Parents Satisfaction '...

\section{Conclusion}

Based on the above discussion can be summarized as follows:.

a. Service Quality partial influence on job performance 4.336 (the t-table 1.980). Based on hypothesis testing a significant difference between Service Quality Satisfaction 'parents, for t-count on the t-table ...

b. School Citra partial influence on job performance 2.440 (the t-table 1.980). Based on hypothesis testing a significant difference between the image of the School Parent Satisfaction, because the t-test on the t-table ...

c. Simultaneous influence of two variables: Quality Care and Education for the image of a parent satisfaction are at 0.815 or $81.5 \%$. Conclusions based on the results of the hypothesis, that the Quality of Service and School of images simultaneously significant effect on Parent Satisfaction '

d. Service Quality (X1) and Parent Satisfaction '(Y) with a value of 0.802 and the relationship is greater than the value of the image relevance Schools 0774 . So the quality of service that most significantly affect parental satisfaction ..

\section{Suggestion}

From these results, suggestions are given author is :

a. There are many other variables that need to be further investigated, to know the things that really significantly influence parental satisfaction.

b. Surabaya School of Management must constantly maintain and improve service quality and image of the school and the parents of students as consumers can meet the needs and expectations of the quality of education that they expect that the reputation of the school in Surabaya can always be maintained in the midst of society, especially in the face of competitive challenges between education providers.

\section{References}

[1]. Nasution, 2004, the "Management Services" Jakarta.

[2]. Kotler, Philip, 2000, Marketing Management, The Millennium Edition, New Jersey: Prentice Hall International Inc...

[3]. Tjiptono, F., \& Chandra, G, 2005, Service Quality \& Satisfaction, Yogyakarta: ANDI

[4]. Norman in Kandampully \& Dwi Suhartanto, 2000:347, Marketing Management

[5]. Nguyen \& LeBlanc, 2002:243, form of architecture, type of product / jasa kualitas communications by any employee organization that interacts with the client.

[6]. Kurtz \& Clow, 1998:4, promotion is done by the company could have an impact on consumer image of the company.

[7]. According to Kelly, 2009, the quality of schools.

[8]. Supranto, J, 2006, Measuring Customer Satisfaction: To Increase Market Share, Jakarta: PT. Rineka Reserved..

[9]. Josep M. Juran on FandyTjiptono, (2005:11), Principles of Total Quality Service ", Yogyakarta Andi..

[10]. DwiSuhartanto Kandampully \& Norman, 2000:347) (10). Marketing Management 
[11]. Nguyen \& LeBlanc, 2002:243), a form of architecture, type of product / jasakualitas communications by any employee organization that interacts with the client..

[12]. Kelly, 2009, Benchmarking for Competitive Advantage, Pitman Publishing, ...

[13]. Sugiyono, 2010. Quantitative Research Methods and R \& D ". Alfabeta, Bandung.

[14]. Tjiptono, Eka., 1997. Principle - the principle of Total Quality Service (TQS). Yogyakarta: Publisher ANDI 